\title{
Efficacy of Vitamin $D_{3}$ Buccal Spray Supplementation Compared to Other Delivery Methods: A Systematic Review of Superiority Randomized Controlled Trials
}

\author{
Maria G. Grammatikopoulou ${ }^{1, *(1)}$, Konstantinos Gkiouras ${ }^{1,2} \oplus$, Meletios P. Nigdelis ${ }^{3}$, \\ Dimitrios P. Bogdanos ${ }^{1,4}$ (D) and Dimitrios G. Goulis ${ }^{3}(\mathbb{D}$ \\ 1 Department of Rheumatology and Clinical Immunology, Faculty of Medicine, School of Health Sciences, \\ University of Thessaly, Larissa GR41110, Greece; kostasgkiouras@hotmail.com (K.G.); \\ bogdanos@med.uth.gr (D.P.B.) \\ 2 Laboratory of Clinical Pharmacology, Medical School, University Campus, \\ Aristotle University of Thessaloniki, Thessaloniki GR54124, Greece \\ 3 Unit of Reproductive Endocrinology, 1st Department of Obstetrics and Gynecology, \\ Medical School, Aristotle University of Thessaloniki, Thessaloniki GR56429, Greece; \\ meletis.nigdelis@gmail.com (M.P.N.);dgg@auth.gr (D.G.G.) \\ 4 Division of Transplantation, Immunology and Mucosal Biology, MRC Centre for Transplantation, \\ King's College London Medical School, London SE5 9RS, UK \\ * Correspondence: mariagram@auth.gr
}

Received: 19 December 2019; Accepted: 29 February 2020; Published: 4 March 2020 updates

\begin{abstract}
Background: Vitamin D deficiency is an important public health concern and supplementation is common for this deficiency. Many different modes of delivering supplementation have been proposed in order to enhance absorption and utilization. The present review compared the efficacy of vitamin $\mathrm{D}_{3}$ buccal spray against other forms of supplementation delivery. (2) Methods: The protocol was registered at PROSPERO (CRD42019136146). Medline/PubMed, CENTRAL and clinicaltrials.gov were searched from their inception until September 2019, for randomized controlled trials (RCTs) that compare vitamin $\mathrm{D}_{3}$ delivery via sublingual spray against other delivery methods. Eligible RCTs involved humans, of any age and health status, published in any language that evaluated changes in plasma $25(\mathrm{OH}) \mathrm{D}$ concentrations. Three reviewers independently extracted data, assessed risk of bias (RoB) and the quality of the trials. (3) Results: Out of 9759 RCTs, four matched the predefined criteria. Intervention duration ranged from 30 days to 3 months whereas vitamin $\mathrm{D}_{3}$ dosage ranged between 800 and $3000 \mathrm{IU} /$ day. One RCT advocated for the superiority of buccal spray in increasing plasma $25(\mathrm{OH}) \mathrm{D}$ concentrations, although several limitations were recorded in that trial. The rest failed to report differences in post-intervention $25(\mathrm{OH}) \mathrm{D}$ concentrations between delivery methods. Considerable clinical heterogeneity was observed due to study design, intervention duration and dosage, assays and labs used to perform the assays, population age and health status, not allowing for synthesis of the results. (4) Conclusions: Based on the available evidence, delivery of vitamin $\mathrm{D}_{3}$ via buccal spray does not appear superior to the other modes of delivery. Future RCTs avoiding the existing methodological shortcomings are warranted.
\end{abstract}

Keywords: vitamin D; cholecalciferol; dietary supplement; oral spray; sublingual spray; oral drops; capsules

\section{Introduction}

Vitamin $\mathrm{D}_{3}$ is an essential fat-soluble nutrient involved in a plethora of metabolic pathways [1-5]. When consumed within the dietary reference level limits, vitamin D exerts multiple health 
benefits [6-8]. Apart from food sources, the majority of vitamin $\mathrm{D}_{3}$ is produced non-enzymatically via ultraviolet-B (UVB) exposure of 7-dehydrocholesterol on skin [6,9-11]. Despite the existence of this additional pathway to increase plasma 25-hydroxycholecalciferol $(25(\mathrm{OH}) \mathrm{D})$ concentrations, vitamin D deficiency remains an important global challenge [12-14] with supplementation being proposed for several conditions including pregnancy [15-19], ageing [20,21], obesity [22-25], infertility [26,27], skeletal health [28], glycemic control [29] and diabetes [30,31], abnormal lipidemic profile [32], cardiovascular [33,34], autoimmune [35-39] and liver disease [40,41].

Determining vitamin D status based on serum 25(OH)D levels remains controversial [11], with some agencies suggesting at least $75 \mathrm{nmol} / \mathrm{L}$ to ensure replete status [42], whereas others recommend $>50$ $\mathrm{nmol} / \mathrm{L}[43,44]$. Maintaining a serum $25(\mathrm{OH}) \mathrm{D}$ concentration above $50 \mathrm{nmol} / \mathrm{L}$ is considered as optimum according to some organizations [43,44], with others advocating against the development of severe deficiency (defined as $25(\mathrm{OH}) \mathrm{D}<25 \mathrm{nmol} / \mathrm{L}$ ) [45]. Given the importance of the vitamin and the relatively frequent shortfall observed in most populations, a variety of recommendations exist [11]. Currently, breastfed infants are required to consume $400 \mathrm{IU}$ daily, and thereafter, an amount of $400-800 \mathrm{IU}$ is recommended each day throughout the life cycle [11,43,44,46], with the exception of the Endocrine Society Guidelines [42], which suggest an even greater upper threshold regarding the reference intake, especially during pregnancy and lactation. Recommendations concerning supplementation dosage and duration remain heterogenous, based on geographical latitude, sun exposure, age, skin phenotype, diagnosed comorbidities that alter vitamin D metabolism, as well as vitamin D and weight status [11].

Apart from supplementation frequency [47], it has been suggested that the mode of supplementary vitamin delivery affects bioavailability, release, and absorption, as well as unstable compounds decomposition [12,48,49]. Subsequently, aside from the typical soft capsule form, several novel delivery methods have been proposed, including gels, oral drops, gums [50] and more recently, sublingual buccal spray [51,52].

Individual randomized controlled trials (RCTs) on the efficacy of vitamin $\mathrm{D}_{3}$ buccal spray suggest its superiority against other modes of delivery [51]. However, given that buccal sprays are approximately double the price of the commonly prescribed capsules, the need for meta-research of the current evidence is vital for consumers and health insurance companies.

Therefore, the aim of the present study was to systematically review individual RCTs that assess the superiority of buccal spray against other modes of vitamin $\mathrm{D}_{3}$ delivery.

\section{Materials and Methods}

\subsection{Search Strategy}

The protocol was registered at PROSPERO (CRD42019136146) and OSF. A comprehensive search was performed in PubMed, Cochrane CENTRAL, and ClinicalTrials.gov for RCTs comparing vitamin $\mathrm{D}_{3}$ supplementation via buccal spray against other delivery methods, from the site's inception until September 2019. Table 1 summarizes the PICO (Population - Intervention - Comparison - Outcome) [53] strategy applied to the study's research question. The keywords used were vitamin $\mathrm{D}$, vitamin $\mathrm{D}_{3}$, cholecalciferol, 25-hydroxycholecalciferol, dietary supplement, buccal spray, oral, drops, administration, calcium, parathyroid hormone, with a combination of medical subheadings (MeSH) terms when applicable. A detailed PubMed search strategy is presented in Figure 1. 
Table 1. PICO strategy for the search question.

\begin{tabular}{|c|c|c|}
\hline PICO & \multicolumn{2}{|r|}{ Description } \\
\hline Population & & Any population, healthy or not \\
\hline Intervention & & Vitamin $\mathrm{D}_{3}$ buccal spray supplementation \\
\hline Comparison & Other & nodes of vitamin $\mathrm{D}_{3}$ supplementation delivery (capsules, drops, etc.) \\
\hline Outcome & & Change in serum $25(\mathrm{OH}) \mathrm{D}$ concentrations \\
\hline \multicolumn{3}{|r|}{ 25(OH)D: 25-hydroxycholecalciferol. } \\
\hline & $\# 1$ & "vitamin D" \\
\hline & & D3 \\
\hline & & Vitamin D [mh] \\
\hline & & cholecalciferol \\
\hline & $\# 5$ & supplement \\
\hline & & "dietary supplement" \\
\hline & & dietary supplements [mh] \\
\hline & & $\# 1 \mathrm{OR} \# 2 \mathrm{OR} \# 3 \mathrm{OR} \# 4$ OR $\# 5$ OR \#6 OR \#7 \\
\hline & & buccal \\
\hline & $\# 10$ & "buccal spray" \\
\hline & $\# 11$ & administration, buccal [mh] \\
\hline & $\# 12$ & drops \\
\hline & $\# 13$ & oral \\
\hline & \#14 & administration, oral [mh] \\
\hline & $\# 15$ & capsule $^{*}$ \\
\hline & \#16 & capsules $[\mathrm{mh}]$ \\
\hline & \#17 & $\# 9$ OR \#10 OR \#11 OR \#12 OR \#13 OR \#14 OR \#15 OR \#16 \\
\hline & $\# 18$ & 25-hydroxycholecalciferol \\
\hline & $\# 19$ & $25(\mathrm{OH}) \mathrm{D}$ \\
\hline & \#20 & 25 hydroxycholecalciferol [mh] \\
\hline & \#21 & calcium \\
\hline & $\# 22$ & $\mathrm{Ca}$ \\
\hline & $\# 23$ & "parathyroid hormone" \\
\hline & $\# 24$ & PTH \\
\hline & $\# 25$ & parathyroid hormone $[\mathrm{mh}]$ \\
\hline & $\# 26$ & $\# 18$ OR \#19 OR \#20 OR \#21 OR \#22 OR \#23 OR \#24 OR \#25 \\
\hline & \#27 & randomized controlled trial [pt] \\
\hline & $\# 28$ & controlled clinical trial [pt] \\
\hline & $\# 29$ & randomized [tiab] \\
\hline & $\# 30$ & drug therapy $[\mathrm{sh}]$ \\
\hline & \#31 & randomly [tiab] \\
\hline & $\# 32$ & trial [tiab] \\
\hline & $\# 33$ & groups [tiab] \\
\hline & \#34 & $\# 27$ OR \#28 OR \#29 OR \#30 OR \#31 OR \#32 OR \#33 \\
\hline & \#35 & animals [mh] \\
\hline & \#36 & humans [mh] \\
\hline & \#37 & \#35 NOT \#36 \\
\hline & $\# 38$ & \#34 NOT \#37 \\
\hline & $\# 39$ & \#8 AND \#17 AND \#26 AND \#38 \\
\hline
\end{tabular}

Figure 1. PubMed search strategy.

\subsection{Search Eligibility Criteria}

Inclusion criteria were RCTs on (1) any population, including healthy participants or patients, (2) populations with low serum 25(OH)D concentrations, (3) of any age group, (4) living in any country, (5) comparing vitamin $\mathrm{D}_{3}$ buccal spray against other routes of vitamin $\mathrm{D}_{3}$ delivery (i.e., oral drops, capsules), (6) performed on humans, (7) using any RCT design, (8) published in any language.

Exclusion criteria involved (1) non-randomized trials, (2) comparing vitamin $\mathrm{D}_{3}$ buccal spray against placebo, or (3) studies performed on animals.

\subsection{Selection of Studies and Interventions of Interest}

Initially, three independent reviewers (M.G.G., K.G. and M.P.N.) identified studies from their titles and abstracts. Full-text articles were retrieved to assist decision-making in cases when deemed necessary. Any disagreement between reviewers was resolved by a senior researcher (D.G.G.). 


\subsection{Data Exctraction}

Two reviewers (M.G.G. and M.P.N.) independently extracted characteristics of the retrieved RCTs and outcomes of interest from full-text articles. Extracted data involved (1) the number of participants at each stage, (2) participant characteristics, (3) study characteristics (registry, design, ethical approval, country, funding), (4) administered dose of vitamin D3 and methods of delivery, (5) intervention duration, (6) washout period (whenever applicable), (7) participant recruitment sites, (8) assays and kits for determining 25(OH)D levels, (9) baseline and post-intervention results (including $25(\mathrm{OH}) \mathrm{D}$, $\mathrm{Ca}$, and parathyroid hormone (PTH) concentrations), (10) recorded adverse events, (11) drop-outs, and (12) analysis performed (intention-to-treat or per protocol).

Data were extracted using a predefined Microsoft Excel data extraction form, including study (design, funding, allocation concealment, protocol registry, country, recruitment site) and participant characteristics (age, health conditions, discontinued/dropouts), intervention details (form, duration, dosage, adverse events), comparators, and clinical outcomes to produce an overview table of all eligible studies.

Characteristics of the retrieved RCTs were evaluated with the Cochrane risk of bias (RoB) 2.0 tool [54] by two reviewers (M.P.N. and M.G.G.) independently, in order to present bias comprehensively. A more experienced author (D.P.B.) assessed between-reviewer differences. The RoB results classified studies as being of "high", "unclear" or "low" risk of bias. Additionally, the Oxford quality scoring system (Jadad score) [55] was applied on each RCT to assess trial quality.

\section{Results}

\subsection{Study Selection}

A total of 9759 studies were screened by title and abstract and 13 were assessed for eligibility criteria (full-text screening), out of which nine were excluded for having a different mode of supplementation delivery, comparing against placebo, or lacking a RCT design. The PRISMA flowchart [39] was applied to illustrate the step-by-step exclusion of unrelated/duplicate retrieved records, leading to the final selection of four RCTs that met the predefined inclusion criteria (Figure 2).

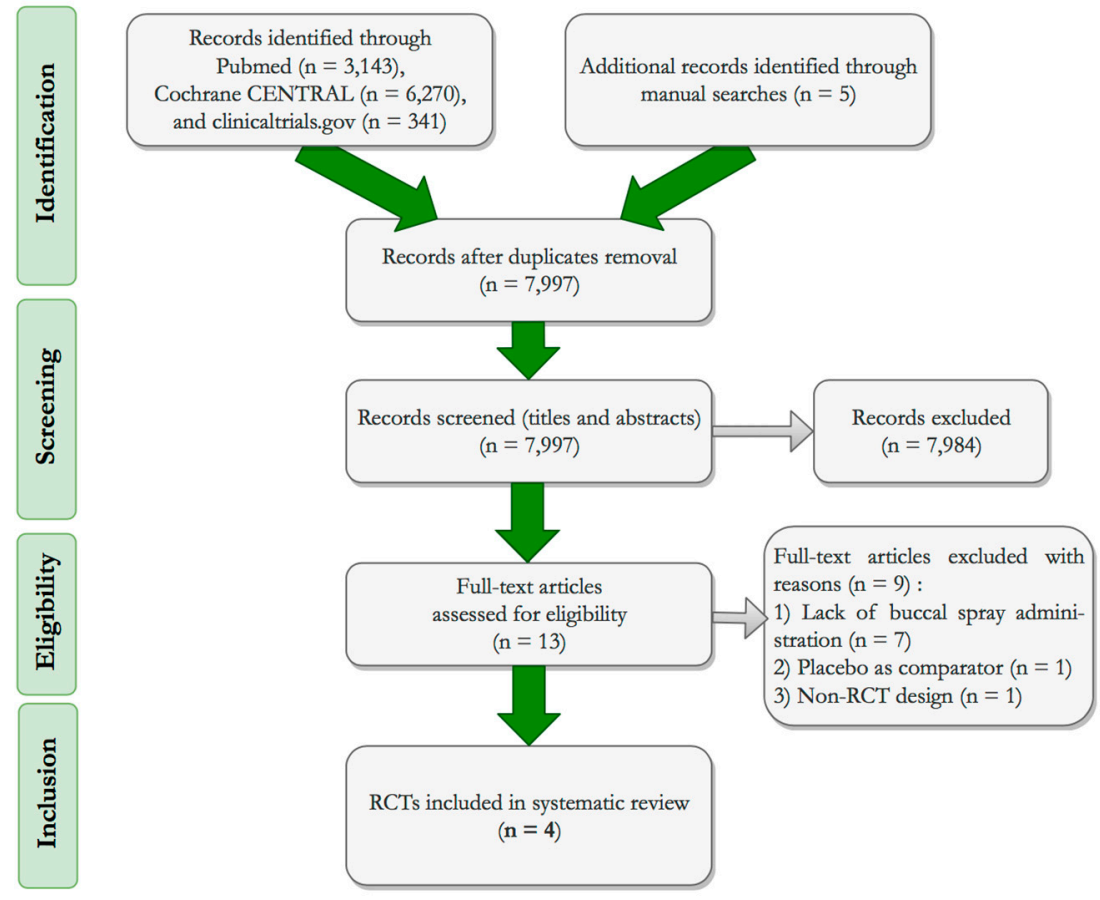

Figure 2. PRISMA flowchart [56] of the studies selection process. 
Table 2. Characteristics of the included randomized controlled trials.

\begin{tabular}{|c|c|c|c|c|}
\hline First Author: & Satia [51] & Todd [57] & Penagini [58] & Williams [59] \\
\hline Implementation year: & NR & $2015-2016$ & $2015-2016$ & 2017 \\
\hline Publication year: & 2015 & 2016 & 2017 & 2019 \\
\hline Design: & Cross-over & Cross-over & Parallel & Parallel \\
\hline Masking: & Single-blinded & Open-label & Open-label & Double-blind \\
\hline Multicenter: & $\sqrt{ }$ & - & - & - \\
\hline Origin: & India & U.K. & Italy & UK \\
\hline Registry: & CTRI/2013/06/003770 & NCT02608164 & NR & NR \\
\hline Funding: & $\begin{array}{c}\text { (1) Buccal spray provided by Pharma } \\
\text { Base SA. }\end{array}$ & $\begin{array}{l}\text { (1) Dept of Employment \& } \\
\text { Learning, N. Ireland } \\
\text { (2) Translational Research Group, } \\
\text { Public Health Agency, Belfast } \\
\text { (3) Buccal spray provided by } \\
\text { BetterYou Ltd. }\end{array}$ & NR & $\begin{array}{l}\text { (1) BetterYou Ltd. } \\
\text { (2) University of Sheffield }\end{array}$ \\
\hline Ethical approval: & Spandan-Ethics & University of Ulster & University of Milan & University of Sheffield \\
\hline $\begin{array}{l}\text { Participant } \\
\text { recruitment: }\end{array}$ & $\begin{array}{l}\text { Two different hospitals, one } \\
\text { physician's site (healthy subjects) and } \\
\text { a gastroenterologist's site (patients } \\
\text { with intestinal malabsorption) }\end{array}$ & $\begin{array}{l}\text { The university and local area } \\
\text { through circular emails and online } \\
\text { advertisements }\end{array}$ & V. Buzzi Children's Hospital & University of Sheffield \\
\hline Participants $(n)$ : & $\begin{array}{c}\mathrm{N}=40 \text { (healthy subjects and patients } \\
\text { with malabsorption syndrome, } \\
\sigma^{x} / \text { ratio }=1 \text { ) } \\
\text { Patients } n=14 \\
\text { Healthy controls } n=14^{\ddagger}\end{array}$ & $\mathrm{N}=22$ healthy adults $(q=12)$ & $\begin{array}{c}\mathrm{N}=24 \text { children } \text { (5-17 years old, } \\
q=14, \text { with neuro-disabilities } \\
\text { and vitamin D deficiency } \\
\quad(\text { cerebral palsy } n=7 \\
\text { symptomatic or genetic epilepsy } \\
n=5, \text { epileptic encephalopathy } \\
n=9, \text { genetic syndromes } n=3 \text { ) }\end{array}$ & $\begin{aligned} \mathrm{N}= & 50^{¥} \text { non-obese, apparently healthy } \\
& \text { adults }(18-50 \text { years old, } q=29)\end{aligned}$ \\
\hline Participant age (years): & $\begin{array}{c}\text { Patients: } 39.9 \pm 11.7 \\
\text { Healthy controls: } 36.2 \pm 10\end{array}$ & $25.2 \pm 6.5$ & $\begin{array}{l}\text { Intervention: } 7.8(5-17)^{\dagger} \\
\text { Comparator: } 9.4(7-16)^{\dagger}\end{array}$ & $\begin{array}{l}\text { Intervention: } 21.7 \pm 3.1 \\
\text { Comparator: } 22.9 \pm 4.8\end{array}$ \\
\hline BMI $\left(\mathrm{kg} / \mathrm{m}^{2}\right)$ : & $\begin{array}{c}\text { Patients: } 21.5 \pm 2.8 \\
\text { Healthy controls: } 23.4 \pm 3.9\end{array}$ & $\begin{array}{l}\text { Intervention: } 24.2 \pm 3.5 \S \\
\text { Comparator: } 24.4 \pm 3.6^{\S}\end{array}$ & $\begin{array}{l}\text { Intervention: } 18.2(12.5-25.5)^{+} \\
\text {Comparator: } 16.9(11.8-24.6)^{\dagger}\end{array}$ & $\begin{array}{c}\text { Intervention: } 23.8 \pm 2.6 \\
\text { Comparator: } 23.6 \pm 3\end{array}$ \\
\hline
\end{tabular}


Table 2. Cont

\begin{tabular}{|c|c|c|c|c|}
\hline First Author: & Satia [51] & Todd [57] & Penagini [58] & Williams [59] \\
\hline Participant Groups $(n)$ : & $\begin{array}{l}\text { Healthy participants: } n=14^{*} \\
\text { Patients: } n=14^{*}\end{array}$ & $\begin{array}{l}\text { Intervention: } n=22 \\
\text { Comparator: } n=22\end{array}$ & $\begin{array}{l}\text { Intervention: } n=12(q=7) \\
\text { Comparator: } n=12(q=7)\end{array}$ & $\begin{array}{l}\text { Intervention: } n=25(\ell=15) \\
\text { Comparator: } n=25(+=14) \\
\text { (1) Active caps + placebo spray: } n=25 \\
\text { (2) Active spray + placebo caps: } n=25 \\
\text { (3) Double placebo: } n=25\end{array}$ \\
\hline Randomization: & Block, by statistician & MINIM software & NR & Block (size of 9), computer-generated \\
\hline $\begin{array}{l}\text { Vitamin D status } \\
\text { definition: }\end{array}$ & None & $\begin{array}{c}\text { Clinical deficiency: } \\
\text { 25(OH)D < 30 nmol/L } \\
\text { Insufficiency: } \\
\text { 25(OH)D } 31-49 \mathrm{nmol} / \mathrm{L} \\
\text { Sufficiency: } 25(\mathrm{OH}) \mathrm{D}>50 \mathrm{nmol} / \mathrm{L}\end{array}$ & $\begin{array}{c}\text { Deficiency: } \\
\text { 25(OH)D } \leq 20 \mathrm{ng} / \mathrm{mL}\end{array}$ & $\begin{array}{l}\text { Deficiency: } 25(\mathrm{OH}) \mathrm{D}<30 \mathrm{nmol} / \mathrm{L} \\
\text { Insufficiency: } 25(\mathrm{OH}) \mathrm{D} 31-46 \mathrm{nmol} / \mathrm{L} \\
\text { Sufficiency: } 25(\mathrm{OH}) \mathrm{D}>50 \mathrm{mmol} / \mathrm{L}\end{array}$ \\
\hline 25(OH)D assay: & ECLIA & LC-MS/MS & Immunoassay & LC-MS \\
\hline Kit: & Roche diagnostics (GmbH, Germany) & $\begin{array}{c}\text { API 4000; AB SCIEX, } \\
\text { Chromsystems Instruments and } \\
\text { Mass-Chrom } 25-\mathrm{OH} \text { vitamin } \mathrm{D}_{3} / \mathrm{D}_{2} ; \\
\text { Chromsystems Instruments \& } \\
\text { Chemicals }(\mathrm{GmbH})\end{array}$ & $\begin{array}{l}\text { 25-Hydroxy Vitamin D EIA, } \\
\text { Immunodiagnostic System, Ltd. }\end{array}$ & finger-prick blood spot \\
\hline Assay laboratory: & $\begin{array}{l}\text { Independent lab (APL Institute of } \\
\text { Clinical Laboratory \& Research Pvt. } \\
\text { Ltd., Ahmedabad, IN) }\end{array}$ & $\begin{array}{l}\text { Independent lab (Biochemistry } \\
\text { Dept of St. James' Hospital, } \\
\text { Dublin, IE) }\end{array}$ & $\begin{array}{l}\text { Pediatric Endocrinology Lab, } \\
\text { Division of Genetics and Cell } \\
\text { Biology, IRCCS San Raffaele } \\
\text { Scientific Institute, Milan, IT }\end{array}$ & $\begin{array}{c}\text { City Assays, Department of Pathology, } \\
\text { Birmingham Sand-well Hospitals NHS } \\
\text { Trust, UK }\end{array}$ \\
\hline Exclusion criteria: & $\sqrt{ }$ & $\sqrt{ }$ & $\sqrt{ }$ & $\sqrt{ }$ \\
\hline Intervention: & $\begin{array}{l}\text { Buccal spray } 2 \text { shots } \times 500 \mathrm{IU} \\
\text { vitamin } \mathrm{D}_{3} / \mathrm{d}\end{array}$ & $\begin{array}{l}\text { Buccal spray } 3000 \mathrm{IU} / \mathrm{d}(75 \mu \mathrm{g}) \\
\text { vitamin } \mathrm{D}_{3}\end{array}$ & $\begin{array}{l}\text { Buccal spray } 800 \mathrm{IU} / \mathrm{d} \\
\text { vitamin } \mathrm{D}_{3}\end{array}$ & $\begin{array}{l}\text { Active vitamin } \mathrm{D}_{3} \text { buccal spray } 3000 \mathrm{IU} \\
\qquad(75 \mu \mathrm{g})+\text { placebo caps }\end{array}$ \\
\hline Comparators: & $\begin{array}{l}\text { (1) soft caps (1000 IU) vitamin } D_{3} / d \\
\text { (2) none }\end{array}$ & $\begin{array}{l}3 \times 1000 \mathrm{IU}(25 \mu \mathrm{g}) \text { vitamin } \mathrm{D}_{3} \\
\text { caps/d, with water }\end{array}$ & Oral drops $750 \mathrm{IU} / \mathrm{d}$ vitamin $\mathrm{D}_{3}$ & $\begin{array}{c}\text { Active vitamin } \mathrm{D}_{3} \text { caps } 3000 \mathrm{IU}(75 \mu \mathrm{g}) \\
+ \text { placebo spray }\end{array}$ \\
\hline Intervention duration: & 30 days & 4 weeks & 3 months & 6 weeks \\
\hline Season: & NR & Winter & Winter & Spring \\
\hline Skin-tone evaluation: & NR & NR & NR & $\sqrt{ }$ \\
\hline Washout duration: & 30 days & 10 weeks & NR & NR \\
\hline
\end{tabular}


Table 2. Cont.

\begin{tabular}{|c|c|c|c|c|}
\hline First Author: & Satia [51] & Todd [57] & Penagini [58] & Williams [59] \\
\hline $\begin{array}{l}\text { Compliance } \\
\text { assessment: }\end{array}$ & $\sqrt{ }$ & $\sqrt{ }$ & $\sqrt{ }$ & $\sqrt{ }$ \\
\hline Dietary intake: & Recorded at baseline & Recorded at baseline & NR & NR \\
\hline Analyses: & $\mathrm{PP}$ & ITT and PP & NR & ITT \\
\hline Outcomes: & $\Delta$ in $25(\mathrm{OH}) \mathrm{D}$ levels & $\begin{array}{c}\Delta \text { in levels of } 25(\mathrm{OH}) \mathrm{D}, \text { creatinine, } \\
\text { PTH, Ca, eGFR }\end{array}$ & $\begin{array}{c}\Delta \text { in levels of } 25(\mathrm{OH}) \mathrm{D}, \mathrm{Ca}, \mathrm{P} \\
\text { PTH, BAP, CTx }\end{array}$ & $\Delta$ in $25(\mathrm{OH}) \mathrm{D}$ levels \\
\hline Dropouts: & $n=2$ (low compliance) & $\begin{array}{c}n=4 \text { ( } 3 \text { went for a sun holiday, no } \\
\text { longer wished to participate and } 1 \\
\text { had illness unrelated to the } \\
\text { intervention) }\end{array}$ & NR (flowchart lacking) & $\begin{array}{c}\text { NR (flowchart lacking) } \\
n=1 \text { stopped due to adverse events } \\
\text { without information on the allocation } \\
\text { group }\end{array}$ \\
\hline $\begin{array}{l}\text { Baseline data } \\
\text { (intervention group): }\end{array}$ & $\begin{array}{c}\text { Healthy subjects: } 18.9 \pm 4.3 \mathrm{ng} / \mathrm{mL}(n \\
=13) \\
\text { Patients: } 10 \pm 4.3 \mathrm{ng} / \mathrm{mL}(n=13)\end{array}$ & $\begin{array}{c}\text { 25(OH)D: } 59.6 \pm 24.4 \mathrm{nmol} / \mathrm{L}(n= \\
22) \\
\text { Dietary vitamin D intake: } 6.3 \pm 6.2 \\
\mu \mathrm{g} / \mathrm{d} \\
\text { PTH: } 50.1 \pm 26 \mathrm{pg} / \mathrm{mL}(n=22) \\
\text { Ca: } 2.2 \pm 0.1 \mathrm{mmol} / \mathrm{L}(n=22)\end{array}$ & $\begin{array}{c}\text { 25(OH)D: } 15.5(8-20)^{\dagger} \mathrm{ng} / \mathrm{mL} \\
\text { PTH: } 72.5(31.4-145.8)^{+} \mathrm{pg} / \mathrm{mL} \\
\text { Ca: } 9.6(9.1-9.8)^{+} \mathrm{mg} / \mathrm{dL}\end{array}$ & $25(\mathrm{OH}) \mathrm{D}: 54.9 \pm 27.8 \mathrm{nmol} / \mathrm{L}(n=25)$ \\
\hline $\begin{array}{l}\text { Baseline data } \\
\text { (comparator group): }\end{array}$ & $\begin{array}{l}\text { Healthy subjects: } 18.7 \pm 5.9 \mathrm{ng} / \mathrm{mL} \\
\qquad(n=13) \\
\text { Patients: } 11 \pm 6.4 \mathrm{ng} / \mathrm{mL}(n=13)\end{array}$ & $\begin{array}{l}25(\mathrm{OH}) \mathrm{D}: 60 \pm 26.3 \mathrm{nmol} / \mathrm{L}(n=22) \\
\text { PTH: } 50.3 \pm 25.5 \mathrm{pg} / \mathrm{mL}(n=22) \\
\text { Ca: } 2.2 \pm 0.1 \mathrm{mmol} / \mathrm{L}(n=22)\end{array}$ & $\begin{array}{l}\text { 25(OH)D: } 11.5(8-19)^{\dagger} \mathrm{ng} / \mathrm{mL} \\
\text { PTH: } 65.9(46-98.8)^{\dagger} \mathrm{pg} / \mathrm{mL} \\
\text { Ca: } 9.4(8.9-10.4)^{\dagger} \mathrm{mg} / \mathrm{dL}\end{array}$ & $25(\mathrm{OH}) \mathrm{D}: 50.7 \pm 19.7 \mathrm{nmol} / \mathrm{L}(n=25)$ \\
\hline $\begin{array}{l}\text { Results } \\
\text { (intervention group): }\end{array}$ & $\begin{array}{c}\text { Healthy subjects: } 26.9 \pm 5.7 \mathrm{ng} / \mathrm{mL} \\
(n=13) \\
\text { Patients: } 20.5 \pm 7.9 \mathrm{ng} / \mathrm{mL}(n=13)\end{array}$ & $\begin{array}{c}\text { 25(OH)D: } 85.8 \pm 19.4 \mathrm{nmol} / \mathrm{L} \\
(n=22) \\
\text { PTH: } 48.2 \pm 27.3 \mathrm{pg} / \mathrm{mL}(n=22) \\
\text { Ca: } 2.2 \pm 0.1 \mathrm{mmol} / \mathrm{L}(n=22)\end{array}$ & $\begin{array}{c}\text { 25(OH)D: } 26.5(13.6-39)^{\dagger} \mathrm{ng} / \mathrm{mL} \\
\text { PTH: } 48.9(23.2-89.6)^{\dagger} \\
\text { Ca: } 9.27(8.7-10)^{\dagger} \mathrm{mg} / \mathrm{dL}\end{array}$ & $25(\mathrm{OH}) \mathrm{D}: 95.8 \pm 28.0 \mathrm{nmol} / \mathrm{L}(n=25)$ \\
\hline $\begin{array}{c}\text { Results } \\
\text { (comparator group): }\end{array}$ & $\begin{array}{l}\text { Healthy subjects: } 22.8 \pm 6.8 \mathrm{ng} / \mathrm{mL} \\
\qquad(n=13) \\
\text { Patients: } 15 \pm 9 \mathrm{ng} / \mathrm{mL}(n=13)\end{array}$ & $\begin{array}{l}\text { 25(OH)D: } 90.4 \pm 21 \mathrm{nmol} / \mathrm{L}(n=22) \\
\text { PTH: } 52.2 \pm 19.3 \mathrm{pg} / \mathrm{mL}(n=22) \\
\text { Ca: } 2.2 \pm 0.1 \mathrm{mmol} / \mathrm{L}(n=22)\end{array}$ & $\begin{array}{c}\text { 25(OH)D: } 34.5(22-49)^{\dagger} \mathrm{ng} / \mathrm{mL} \\
\text { PTH: } 53.5(30.6-98.4)^{+} \mathrm{pg} / \mathrm{mL} \\
\text { Ca: } 9.19(8.6-9.8)^{\dagger} \mathrm{mg} / \mathrm{dL}\end{array}$ & 25(OH)D: $91.4 \pm 19.8 \mathrm{nmol} / \mathrm{L}(n=25)$ \\
\hline Results overall: & $\begin{array}{l}\text { The buccal spray significantly } \\
\text { increased serum } 25(\mathrm{OH}) \mathrm{D} \text { levels as } \\
\text { compared to the caps, in both healthy } \\
\text { subjects and patients with } \\
\text { malabsorption syndrome }\end{array}$ & $\begin{array}{l}\text { No difference between buccal spray } \\
\text { and caps }\end{array}$ & $\begin{array}{l}\text { Vitamin } \mathrm{D}_{3} \text { supplementation } \\
\text { with buccal spray and oral } \\
\text { drops are equally effective }\end{array}$ & $\begin{array}{c}\text { Vitamin } \mathrm{D}_{3} \text { supplementation via } \\
\text { capsules and sublingual spray are } \\
\text { equally effective }\end{array}$ \\
\hline
\end{tabular}


Table 2. Cont

\begin{tabular}{|c|c|c|c|c|}
\hline First Author: & Satia [51] & Todd [57] & Penagini [58] & Williams [59] \\
\hline Adverse events: & NR & NR & NR & $n=2$ small blisters on cheek and tongue \\
\hline RCT Issues: & NR & NR & $\begin{array}{l}\text { The dosage could not be } \\
\text { matched precisely between the } \\
\text { two interventions. }\end{array}$ & $\begin{array}{l}\text { Dose inconsistency: The spray/caps } \\
\text { content was prepared to } 97.5 \mu \mathrm{g} / \mathrm{dose} \text { in } \\
\text { order to maintain shelf life and } \\
\text { guarantee dose, however, each capsule } \\
\text { and spray contained } 3000 \mathrm{IU}(75 \mu \mathrm{g}) \text { of } \\
\text { vitamin } \mathrm{D}_{3} \text { per dose. }\end{array}$ \\
\hline Manuscript issues: & - & ITT and PP were not separated & $\begin{array}{l}\text { No flowchart, no detailed } n \text { in } \\
\text { each stage }\end{array}$ & No flowchart \\
\hline Jadad [55] score: & 2 & 2 & -1 & 4 \\
\hline
\end{tabular}

BAP: bone-specific alkaline phosphatase; BMI: Body Mass Index; Ca: Calcium; CTRI: Clinical Trial Registry India; CTx: C-terminal telopeptide of type I collagen; ECLIA: Electrochemiluminescence; $e G F R$ : estimated glomerular filtration rate; ITT: Intention to treat; IU: international units; LC-MS/MS: liquid chromatography-tandem mass spectrometry; NR: Not Reported; PP: Per Protocol; PTH: Parathyroid Hormone; RCT: Randomized Controlled Trial; 25(OH)D: 25-hydroxycholecalciferol. * Same $n$ in intervention and comparator treatments for either group; ${ }^{\dagger}$ Expressed as median (range); $\ddagger$ Total $n$ was 20 in each group, but the second comparator (placebo) was omitted from the present analyses; ${ }^{*}$ The second comparator (placebo), was omitted from the present analyses $(n=25) ; \S$ At initial allocation, as this was a cross-over study; 
Table 2 summarizes the characteristics of the retrieved RCTs. Two trials [51,57] had a crossover design, and the remaining two [58,59] used parallel interventions. One RCT was multicenter [51] and single-blinded. The rest were single-center, two of which used open-label $[57,58]$ and one used double-blind masking [59]. Intervention duration ranged between 30 days to 3 months and was mainly performed during winter time. Only one RCT [59] evaluated participants' skin tone during the study. Vitamin $\mathrm{D}_{3}$ dosage ranged from 800 [58] to 3000 [57,59] IU per day. As far as participants are concerned, Satia [51], Todd [57] and Williams [59] used adult samples, whereas Penagini [58] recruited children with neuro-disabilities. On the other hand, Satia [51] included two participant arms, one consisting of healthy subjects, and the other comprising patients with malabsorption syndrome. The Todd [57] trial was restricted to the recruitment of healthy adults.

Satia [51] and Williams [59] also compared against a placebo, but these comparisons were omitted from the present analyses for not fulfilling the "superiority" comparison criterion.

\subsection{Risk of Bias and Quality Assessment of Studies}

The risk of bias of the included studies is illustrated in Table 3. The Penagini [58] trial was assessed as having a high-risk of overall bias, for lacking a predefined protocol, randomization, and funding disclosure. Williams and associates [59] also conducted a trial of high overall bias, given that the predefined intervention duration was not kept. The RCT by Satia [51] was of unclear bias, with substantial deviations from the reported intended interventions.

Table 3. Summary risk of bias [54] assessment of the included randomized controlled trials.

\begin{tabular}{ccccccc}
\hline & $\begin{array}{c}\text { Randomization } \\
\text { Process }\end{array}$ & $\begin{array}{c}\text { Deviations } \\
\text { from } \\
\text { Intended } \\
\text { Interventions }\end{array}$ & $\begin{array}{c}\text { Missing } \\
\text { Outcome } \\
\text { Data }\end{array}$ & $\begin{array}{c}\text { Measurement } \\
\text { of the } \\
\text { Outcome }\end{array}$ & $\begin{array}{c}\text { Selection } \\
\text { of the } \\
\text { Reported } \\
\text { Result }\end{array}$ & $\begin{array}{c}\text { Overall } \\
\text { Bias }\end{array}$ \\
\hline Satia [51] & + & $\odot$ & + & + & + & $?$ \\
\hline Todd [57] & $\odot$ & + & + & + & + & + \\
\hline Penagini [58] & $\odot$ & $\odot$ & + & $?$ & $?$ & $\odot$ \\
\hline Williams [59] & + & $?$ & + & $\odot$ & $?$ & $\bullet$ \\
\hline
\end{tabular}

Quality assessment of the RCTs based on the Jadad [55] scale (Table 2) revealed that the Satia [51] and Todd [57] trials exhibited several bias-related issues. On the other hand, the RCT performed by Penagini [58] demonstrated the most quality issues, including bias in the randomization process, deviations from the intended interventions, overall bias and unclear risk outcomes measurement and selective reporting. In contrast, the study conducted by Williams [59] received the highest quality score among all of the studies. Additionally, Todd [57] failed to separate the intention-to-treat from the per-protocol analyses, whereas Penagini [58] and Williams [59] lacked many of the CONSORT [60] components, including a flow diagram or details concerning dropouts and the number of participants at each stage. None of the RCTs reported any post-intervention adverse event, except Williams et al. [59] who reported small blisters on the cheek and tongue of two participants.

Satia [51] was the only one who advocated for the superiority of vitamin $\mathrm{D}_{3}$ buccal spray against the other modes of delivery in increasing plasma $25(\mathrm{OH}) \mathrm{D}$ concentrations. The remaining three RCTs [57-59] did not report any difference between intervention and comparator groups, and indicated the similarity and equal efficacy between different modes of vitamin $\mathrm{D}_{3}$ delivery.

\section{Discussion}

Although a variety of delivery methods exist for most dietary supplements, systematic reviews and meta-analyses on the efficacy of each mode are lacking. The present systematic review indicates that 
vitamin $\mathrm{D}_{3}$ delivery via buccal spray does not differ from other supplementation methods in increasing plasma $25(\mathrm{OH}) \mathrm{D}$ levels. In parallel, the small number of retrieved RCTs and the high degree of clinical heterogeneity among them did not allow for a safe synthesis of the results as initially intended.

The Satia [51] trial was the only one that reported positive findings regarding the superiority of vitamin $\mathrm{D}_{3}$ delivery via buccal spray compared to capsules. However, the trial has limitations regarding the washout duration. According to Senn [61], if the duration of the washout is reasonable, substantial carry-over effects are unlikely to occur. On the other hand, as Todd and associates [57] note, the washout duration must be based on the US Food and Drug Administration (FDA) rule of thumb $[62,63]$, which is five times the plasma half-life of the measured substance, herein $25(\mathrm{OH}) \mathrm{D}$, is needed to achieve elimination of more than $95 \%$ of the substance from the body. Given that the plasma half-life of total 25(OH)D is approximately 15 days [64], ten weeks are needed to wash out any supplementation effect. Thus, based on the FDA guidelines, the duration of washout carried out by Satia [51] (10 days) appears inadequate.

According to the literature, interpretation of vitamin D assay results should be performed with caution, as not all methods are equal [65]. Farrell [66] revealed that automated immunoassays tend to demonstrate variable performance, and often fail to meet specific performance goals. On the other hand, the liquid chromatography-tandem mass spectrometry (LC-MS/MS) method used by Todd [57] tends to exhibit greater accuracy, lower variability and less bias $[65,66]$. Apart from the distinct assays, all three trials used independent laboratories and this has been shown to produce further variations in the results [67], as most laboratories fail to adhere to quality assurance standards and comply with international standardization processes.

Apart from the low Jadad [55] score and high risk of bias, the Penagini [58] trial demonstrated several additional shortcomings. Except for supplements, two known physiological pathways exist for increasing $25(\mathrm{OH}) \mathrm{D}$ concentrations, with the first being epidermal synthesis via sun exposure and the second through dietary intake. Concerning the latter, several studies suggest that vitamin D absorption is enhanced with concomitant fat intake or other oily vehicles [68]. Penagini [58] did not report controlling for these factors, failed to state the season in which the intervention was implemented and to include the assessment of usual dietary vitamin D intake, which introduces possible bias in the trial results. According to Rees [69], lifestyle variations account for one half of the variability in vitamin D supplementation response; thus, all trials should adjust for these factors in advance.

An additional limitation of the included RCTs is the lack of vitamin D genetic variants assay. As with most procedures in the human body, vitamin D absorption and utilization are also epiphenomena related to hereditary susceptibility, which suggests a personalized response $[10,70]$. Hence, genetic variations in 25-hydroxylase and vitamin D-binding protein have been shown to alter supplementation response [71,72], although the produced effect appears small compared to that of lifestyle components [69]. However, none of the included RCTs reported assessing vitamin D genetic variants or controlling for them during sample recruitment and group allocation.

Taking into account all of the above issues, the clinical heterogeneity of the retrieved RCTs appears to be multifactorial, which stems from the different study design, assays and laboratories used to perform the assays, intervention dosage, duration and season, washout duration, participant age and health status, allocation concealment and usual dietary intake. Although individually these factors are often encountered in meta-analyses, when only four trials are concerned, the coexistence of all these factors exacerbates heterogeneity and does not allow for a safe synthesis of the results. Indeed, in an attempt to pool findings (K.G.), considerable statistical heterogeneity was observed; thus, we considered that based on the currently available evidence at this time, a systematic review would be more robust compared to a meta-analysis.

Secondary analyses and synthesis of the findings of trials assessing the efficacy of vitamin D supplementation are required to produce robust results [73]. To this point, there are no other published systematic reviews that evaluate different modes of delivering dietary supplements. The present review was structured to assess the efficacy of vitamin $\mathrm{D}_{3}$ supplementation from a different point 
of view: the superiority of buccal spray mode of delivery. Of note, one protocol for a systematic review with some similar features was published approximately a year ago (CRD42018118580) [74], although no preliminary or final findings have been reported until now. Distinct differences exist between the two protocols, with the present one focusing solely on vitamin $\mathrm{D}_{3}$, using a RCT design as an inclusion criterion, while assessing any form of vitamin $\mathrm{D}_{3}$ oral spray supplementation delivery. On the other hand, the other protocol [74] reported the inclusion of any quasi-experimental study, focuses on both vitamin $\mathrm{D}_{2}$ and $\mathrm{D}_{3}$ intervention studies, while excluding spray interventions applied to the buccal mucosa, as performed in the Williams [59] trial included herein (use of sublingual spray). Additionally, a variety of methodological differences can be observed, including the search strategy, databases, search strings and keyword combinations applied, the tools used for assessing the quality and bias of studies (with the Jadad [55] and RoB 2.0 [54] being used herein, compared to the Joanna Briggs Institute (JBI) and GRADE [75] applied in the other protocol), and distinct data extraction protocols. In comparison to the aforementioned protocol [74], the present review has more restrictions with regard to the search strategy, as well as concerning the eligibility criteria, narrowing down the results to a great extent, while differentiating primary outcomes synthesis. Subsequently, based on the distinct methodological designs, inclusion/exclusion criteria, search strategy and vitamin D form based on the reported PICOs, the two studies would be expected to retrieve different primary studies, resulting in distinctive findings overall. Saldanha [76] noted that even when similar interventions are compared in trials or systematic reviews, differences in perspectives, goals, and constraints between trialists and reviewers explain differences in the outcomes. Nevertheless, as in primary research, also in meta-research, studies addressing similar research questions are required to inform practice and produce more robust recommendations. Given that $67 \%$ of the published meta-analyses tend to have at least one other overlapping meta-analysis, with a median of two meta-analyses per topic [77], and the fact that many differences exist between the two protocols, the two systematic reviews are expected to yield different findings based on a distinct qualitative synthesis of primary studies and are both required.

\section{Conclusions}

Thorough examination and critical appraisal of the current evidence reveals that despite the higher economic cost of the buccal spray, it does not appear to be superior to the other modes of vitamin $D_{3}$ delivery. More RCTs are required to investigate its efficacy in distinct populations, including patients with malabsorption problems. The limitations of the existing trials highlighted herein could serve as a primer for the design of future, relevant RCTs in order to reduce heterogeneity, increase trial comparability, and increase the validity of individual RCT results. Nevertheless, vitamin $\mathrm{D}_{3}$ delivery via buccal spray might be preferred by populations with swallowing problems, or those receiving a great variety of supplements and/or medications, who wish to limit their intake of pills and capsules.

Author Contributions: All authors have read and agree to the published version of the manuscript. Conceptualization, D.G.G. and M.G.G.; methodology, D.G.G., M.G.G., and K.G.; protocol drafting, K.G. and D.P.B.; risk of bias, M.P.N., M.G.G. and D.P.B.; quality assessment, K.G. and D.P.B.; data extraction, M.G.G., M.P.N. and K.G.; literature search, M.G.G., K.G. and M.P.N.; search flowchart, M.P.N.; writing-original draft preparation, M.G.G., D.G.G. and D.P.B.; writing-review and editing, M.P.N. and K.G.; supervision, D.G.G.

Funding: This research received no external funding.

Acknowledgments: The authors appreciate the help provided by Dimitrios I. Athanasiadis, post-doctoral research fellow at the Department of Surgery, Division of Bariatric Surgery, Indiana University School of Medicine, Indianapolis, USA during the search process (database access). The present work was presented at the 12th International Congress on Autoimmunity, held in Athens, Greece.

Conflicts of Interest: The authors declare no conflict of interest. 


\section{References}

1. Whiting, S.J.; Calvo, M.S.; Vatanparast, H. Current Understanding of Vitamin D Metabolism, Nutritional Status, and Role in Disease Prevention. In Nutrition in the Prevention and Treatment of Disease; Academic Press: Cambridge, MA, USA, 2017; pp. 937-967.

2. Park, J.E.; Pichiah, P.B.T.; Cha, Y.-S. Vitamin D and Metabolic Diseases: Growing Roles of Vitamin D. J. Obes. Metab. Syndr. 2018, 27, 223-232. [CrossRef] [PubMed]

3. Gil, Á.; Plaza-Diaz, J.; Mesa, M.D. Vitamin D: Classic and Novel Actions. Ann. Nutr. Metab. 2018, 72, 87-95. [CrossRef] [PubMed]

4. Sassi, F.; Tamone, C.; D'Amelio, P. Vitamin D: Nutrient, Hormone, and Immunomodulator. Nutrients 2018, 10, 1656. [CrossRef] [PubMed]

5. Francic, V.; Ursem, S.R.; Dirks, N.F.; Keppel, M.H.; Theiler-Schwetz, V.; Trummer, C.; Pandis, M.; Borzan, V.; Grübler, M.R.; Verheyen, N.D.; et al. The Effect of Vitamin D Supplementation on its Metabolism and the Vitamin D Metabolite Ratio. Nutrients 2019, 11, 2539. [CrossRef] [PubMed]

6. Hanel, A.; Carlberg, C. Vitamin D and evolution: Pharmacologic implications. Biochem. Pharmacol. 2019. [CrossRef]

7. Carlberg, C. Vitamin D: A Micronutrient Regulating Genes. Curr. Pharm. Des. 2019, 25, 1740-1746. [CrossRef]

8. Christakos, S.; Li, S.; De La Cruz, J.; Bikle, D.D. New developments in our understanding of vitamin metabolism, action and treatment. Metabolism 2019, 98, 112-120. [CrossRef]

9. Anastasiou, A.; Karras, S.N.; Bais, A.; Grant, W.B.; Kotsa, K.; Goulis, D.G. Ultraviolet radiation and effects on humans: The paradigm of maternal vitamin D production during pregnancy. Eur. J. Clin. Nutr. 2017, 71, 1268-1272. [CrossRef]

10. Carlberg, C. Nutrigenomics of Vitamin D. Nutrients 2019, 11, 676. [CrossRef]

11. Bouillon, R. Comparative analysis of nutritional guidelines for vitamin D. Nat. Rev. Endocrinol. 2017, 13, 466-479. [CrossRef]

12. Rejinold, N.S.; Kim, H.K.; Isakovic, A.F.; Gater, D.L.; Kim, Y.-C. Therapeutic vitamin delivery: Chemical and physical methods with future directions. J. Control. Release 2019, 298, 83-98. [CrossRef] [PubMed]

13. Holick, M.F. The vitamin D deficiency pandemic: Approaches for diagnosis, treatment and prevention. Rev. Endocr. Metab. Disord. 2017, 18, 153-165. [CrossRef] [PubMed]

14. Karras, S.; Paschou, S.A.; Kandaraki, E.; Anagnostis, P.; Annweiler, C.; Tarlatzis, B.C.; Hollis, B.W.; Grant, W.B.; Goulis, D.G. Hypovitaminosis D in pregnancy in the Mediterranean region: A systematic review. Eur. J. Clin. Nutr. 2016, 70, 979-986. [CrossRef] [PubMed]

15. Karras, S.N.; Anagnostis, P.; Naughton, D.; Annweiler, C.; Petroczi, A.; Goulis, D.G. Vitamin D during pregnancy: Why observational studies suggest deficiency and interventional studies show no improvement in clinical outcomes? A narrative review. J. Endocrinol. Invest. 2015, 38, 1265-1275. [CrossRef]

16. Karras, S.; Anagnostis, P.; Petroczi, A.; Annweiler, C.; Naughton, D.; Goulis, D. Maternal vitamin D status in pregnancy: A critical appraisal of current analytical data on maternal and neonatal outcomes. Hormones 2015, 14, 224-231. [CrossRef]

17. Janbek, J.; Specht, I.O.; Heitmann, B.L. Associations between vitamin D status in pregnancy and offspring neurodevelopment: A systematic literature review. Nutr. Rev. 2019, 77, 330-349. [CrossRef]

18. Gallo, S.; McDermid, J.M.; Al-Nimr, R.I.; Hakeem, R.; Moreschi, J.M.; Pari-Keener, M.; Stahnke, B.; Papoutsakis, C.; Handu, D.; Cheng, F.W. Vitamin D Supplementation during Pregnancy: An Evidence Analysis Center Systematic Review and Meta-Analysis. J. Acad. Nutr. Diet. 2019. [CrossRef]

19. Palacios, C.; Kostiuk, L.K.; Peña-Rosas, J.P. Vitamin D supplementation for women during pregnancy. Cochrane Database Syst. Rev. 2019, 10, CD013446. [CrossRef]

20. Caristia, S.; Filigheddu, N.; Barone-Adesi, F.; Sarro, A.; Testa, T.; Magnani, C.; Aimaretti, G.; Faggiano, F.; Marzullo, P. Vitamin D as a Biomarker of Ill Health among the Over-50s: A Systematic Review of Cohort Studies. Nutrients 2019, 11, 2384. [CrossRef]

21. Ruggiero, C.; Baroni, M.; Bini, V.; Brozzetti, A.; Parretti, L.; Zengarini, E.; Lapenna, M.; Antinolfi, P.; Falorni, A.; Mecocci, P.; et al. Effects of Weekly Supplementation of Cholecalciferol and Calcifediol Among the Oldest-Old People: Findings From a Randomized Pragmatic Clinical Trial. Nutrients 2019, 11, 2778. [CrossRef]

22. Perna, S. Is Vitamin D Supplementation Useful for Weight Loss Programs? A Systematic Review and Meta-Analysis of Randomized Controlled Trials. Medicina (B. Aires) 2019, 55, 368. [CrossRef] [PubMed] 
23. Bassatne, A.; Chakhtoura, M.; Saad, R.; Fuleihan, G.E.-H. Vitamin D supplementation in obesity and during weight loss: A review of randomized controlled trials. Metabolism 2019, 92, 193-205. [CrossRef] [PubMed]

24. Migliaccio, S.; Di Nisio, A.; Mele, C.; Scappaticcio, L.; Savastano, S.; Colao, A. Obesity and hypovitaminosis D: Causality or casualty? Int. J. Obes. Suppl. 2019, 9, 20-31. [CrossRef] [PubMed]

25. Figueiredo, A.C.C.; Carrilho, T.R.B.; Batalha, M.A.; Farias, D.R.; Barros, E.G.; Kac, G. Association between vitamin $\mathrm{D}$ status during pregnancy and total gestational weight gain and postpartum weight retention: A prospective cohort. Eur. J. Clin. Nutr. 2019, 77, 890-902. [CrossRef]

26. Bosdou, J.; Konstantinidou, E.; Anagnostis, P.; Kolibianakis, E.; Goulis, D. Vitamin D and Obesity: Two Interacting Players in the Field of Infertility. Nutrients 2019, 11, 1455. [CrossRef]

27. Hosseini Marnani, E.; Mollahosseini, M.; Gheflati, A.; Ghadiri-Anari, A.; Nadjarzadeh, A. The effect of vitamin D supplementation on the androgenic profile in men: A systematic review and meta-analysis of clinical trials. Andrologia 2019, 51, e13343. [CrossRef]

28. Anagnostis, P.; Paschou, S.A.; Goulis, D.G. Calcium and Vitamin D Supplements and Fractures in Community-Dwelling Adults. JAMA 2018, 319, 2041. [CrossRef]

29. Ojo, O.; Weldon, S.M.; Thompson, T.; Vargo, E.J. The Effect of Vitamin D Supplementation on Glycaemic Control in Women with Gestational Diabetes Mellitus: A Systematic Review and Meta-Analysis of Randomised Controlled Trials. Int. J. Environ. Res. Public Health 2019, 16, 1716. [CrossRef]

30. Mousa, A.; Naderpoor, N.; Teede, H.; Scragg, R.; de Courten, B. Vitamin D supplementation for improvement of chronic low-grade inflammation in patients with type 2 diabetes: A systematic review and meta-analysis of randomized controlled trials. Nutr. Rev. 2018, 76, 380-394. [CrossRef]

31. Pittas, A.G.; Dawson-Hughes, B.; Sheehan, P.; Ware, J.H.; Knowler, W.C.; Aroda, V.R.; Brodsky, I.; Ceglia, L.; Chadha, C.; Chatterjee, R.; et al. Vitamin D Supplementation and Prevention of Type 2 Diabetes. N. Engl. J. Med. 2019, 381, 520-530. [CrossRef]

32. Dibaba, D.T. Effect of vitamin D supplementation on serum lipid profiles: A systematic review and meta-analysis. Nutr. Rev. 2019, 77, 890-902. [CrossRef]

33. Anagnostis, P.; Paschou, S.A.; Goulis, D.G. Vitamin D Supplementation and Cardiovascular Disease Risk. JAMA Cardiol. 2017, 2, 1281. [CrossRef] [PubMed]

34. Barbarawi, M.; Kheiri, B.; Zayed, Y.; Barbarawi, O.; Dhillon, H.; Swaid, B.; Yelangi, A.; Sundus, S.; Bachuwa, G.; Alkotob, M.L.; et al. Vitamin D Supplementation and Cardiovascular Disease Risks in More Than 83000 Individuals in 21 Randomized Clinical Trials. JAMA Cardiol. 2019. [CrossRef] [PubMed]

35. Smyk, D.S.; Mavropoulos, A.; Mieli-Vergani, G.; Vergani, D.; Lenzi, M.; Bogdanos, D.P. The Role of Invariant NKT in Autoimmune Liver Disease: Can Vitamin D Act as an Immunomodulator? Can. J. Gastroenterol. Hepatol. 2018, 2018, 8197937. [CrossRef] [PubMed]

36. Smyk, D.S.; Orfanidou, T.; Invernizzi, P.; Bogdanos, D.P.; Lenzi, M. Vitamin D in autoimmune liver disease. Clin. Res. Hepatol. Gastroenterol. 2013, 37, 535-545. [CrossRef] [PubMed]

37. Efe, C.; Kav, T.; Aydin, C.; Cengiz, M.; Imga, N.N.; Purnak, T.; Smyk, D.S.; Torgutalp, M.; Turhan, T.; Ozenirler, S.; et al. Low Serum Vitamin D Levels Are Associated with Severe Histological Features and Poor Response to Therapy in Patients with Autoimmune Hepatitis. Dig. Dis. Sci. 2014, 59, 3035-3042. [CrossRef]

38. Zheng, R.; Gonzalez, A.; Yue, J.; Wu, X.; Qiu, M.; Gui, L.; Zhu, S.; Huang, L. Efficacy and Safety of Vitamin D Supplementation in Patients With Systemic Lupus Erythematosus: A Meta-analysis of Randomized Controlled Trials. Am. J. Med. Sci. 2019, 358, 104-114. [CrossRef]

39. Infante, M.; Ricordi, C.; Sanchez, J.; Clare-Salzler, M.J.; Padilla, N.; Fuenmayor, V.; Chavez, C.; Alvarez, A.; Baidal, D.; Alejandro, R.; et al. Influence of Vitamin D on Islet Autoimmunity and Beta-Cell Function in Type 1 Diabetes. Nutrients 2019, 11, 2185. [CrossRef]

40. Bjelakovic, G.; Nikolova, D.; Bjelakovic, M.; Gluud, C. Vitamin D supplementation for chronic liver diseases in adults. Cochrane Database Syst. Rev. 2017, 11, CD011564. [CrossRef]

41. Yodoshi, T.; Orkin, S.; Arce-Clachar, A.C.; Bramlage, K.; Liu, C.; Fei, L.; El-Khider, F.; Dasarathy, S.; Xanthakos, S.A.; Mouzaki, M. Vitamin D deficiency: Prevalence and association with liver disease severity in pediatric nonalcoholic fatty liver disease. Eur. J. Clin. Nutr. 2019. [CrossRef]

42. Holick, M.F.; Binkley, N.C.; Bischoff-Ferrari, H.A.; Gordon, C.M.; Hanley, D.A.; Heaney, R.P.; Murad, M.H.; Weaver, C.M. Endocrine Society Evaluation, Treatment, and Prevention of Vitamin D Deficiency: An Endocrine Society Clinical Practice Guideline. J. Clin. Endocrinol. Metab. 2011, 96, 1911-1930. [CrossRef] [PubMed] 
43. Institute of Medicine. Dietary Reference Intakes for Calcium and Vitamin D; Ross, A.C., Taylor, C.L., Yaktine, A.L., Del Valle, H.B., Eds.; Bethesda: Rockville, MD, USA, 2011.

44. Paxton, G.A.; Teale, G.R.; Nowson, C.A.; Mason, R.S.; McGrath, J.J.; Thompson, M.J.; Siafarikas, A.; Rodda, C.P.; Munns, C.F.; Australian and New Zealand Bone and Mineral Society; et al. Vitamin D and health in pregnancy, infants, children and adolescents in Australia and New Zealand: A position statement. Med. J. Aust. 2013, 198, 142-143. [CrossRef] [PubMed]

45. National Institute of Health and Care Excellence. Vitamin D: Supplement Use in Specific Population Groups. Public health guideline. 2014. Available online: https://www.nice.org.uk/guidance/ph56/resources/vitamind-supplement-use-in-specific-population-groups-pdf-1996421765317 (accessed on 19 November 2019).

46. EFSA Panel on Dietetic Products, Nutrition and Allergies (NDA). Dietary reference values for vitamin D. EFSA J. 2016, 14, e04547. [CrossRef]

47. Dalle Carbonare, L.; Valenti, M.; del Forno, F.; Piacentini, G.; Pietrobelli, A. Vitamin D Daily versus Monthly Administration: Bone Turnover and Adipose Tissue Influences. Nutrients 2018, 10, 1934. [CrossRef]

48. Maurya, V.K.; Bashir, K.; Aggarwal, M. Vitamin D microencapsulation and fortification: Trends and technologies. J. Steroid Biochem. Mol. Biol. 2019, 105489. [CrossRef]

49. Mentaverri, R.; Souberbielle, J.-C.; Brami, G.; Daniel, C.; Fardellone, P. Pharmacokinetics of a New Pharmaceutical Form of Vitamin D3 100,000 IU in Soft Capsule. Nutrients 2019, 11, 703. [CrossRef]

50. Wagner, C.L.; Shary, J.R.; Nietert, P.J.; Wahlquist, A.E.; Ebeling, M.D.; Hollis, B.W. Bioequivalence Studies of Vitamin D Gummies and Tablets in Healthy Adults: Results of a Cross-Over Study. Nutrients 2019, 11, 1023. [CrossRef] [PubMed]

51. Satia, M.; Mukim, A.; Tibrewala, K.; Bhavsar, M. A randomized two way cross over study for comparison of absorption of vitamin D3 buccal spray and soft gelatin capsule formulation in healthy subjects and in patients with intestinal malabsorption. Nutr. J. 2015, 14, 114. [CrossRef] [PubMed]

52. Glowka, E.; Stasiak, J.; Lulek, J. Drug Delivery Systems for Vitamin D Supplementation and Therapy. Pharmaceutics 2019, 11, 347. [CrossRef] [PubMed]

53. Fineout-Overholt, E.; Johnston, L. Teaching EBP: Asking Searchable, Answerable Clinical Questions. Worldviews Evidence-Based Nurs. 2005, 2, 157-160. [CrossRef] [PubMed]

54. Sterne, J.A.C.; Savović, J.; Page, M.; Elbers, R.; Blencowe, N.; Boutron, I.; Cates, C.; Cheng, H.-Y.; Corbett, M.; Eldridge, S.; et al. RoB 2: A revised tool for assessing risk of bias in randomised trials. Br. Med. J. 2019, 366, 14898. [CrossRef] [PubMed]

55. Jadad, A.R.; Moore, R.A.; Carroll, D.; Jenkinson, C.; Reynolds, D.J.; Gavaghan, D.J.; McQuay, H.J. Assessing the quality of reports of randomized clinical trials: Is blinding necessary? Control. Clin. Trials 1996, 17, 1-12. [CrossRef]

56. Moher, D.; Liberati, A.; Tetzlaff, J.; Altman, D.G.; Group, T.P. Preferred Reporting Items for Systematic Reviews and Meta-Analyses: The PRISMA Statement. PLoS Med. 2009, 6, e1000097. [CrossRef] [PubMed]

57. Todd, J.J.; McSorley, E.M.; Pourshahidi, L.K.; Madigan, S.M.; Laird, E.; Healy, M.; Magee, P.J. Vitamin D3 supplementation in healthy adults: A comparison between capsule and oral spray solution as a method of delivery in a wintertime, randomised, open-label, cross-over study. Br. J. Nutr. 2016, 116, 1402-1408. [CrossRef] [PubMed]

58. Penagini, F.; Borsani, B.; Maruca, K.; Giosia, V.; Bova, S.; Mastrangelo, M.; Zuccotti, G.V.; Mora, S. Short-Term Vitamin D Supplementation in Children with Neurodisabilities: Comparison of Two Delivery Methods. Horm. Res. Paediatr. 2017, 88, 281-284. [CrossRef]

59. Williams, C.E.; Williams, E.A.; Corfe, B.M. Rate of change of circulating 25-hydroxyvitamin D following sublingual and capsular vitamin D preparations. Eur. J. Clin. Nutr. 2019, 73, 1630-1635. [CrossRef]

60. Schulz, K.F.; Altman, D.G.; Moher, D. coNSorT 2010 Statement: Updated guidelines for reporting parallel group randomised trials. BMJ 2010, 340,332. [CrossRef]

61. Secnn, S.; D'Angelo, G.; Potvin, D. Carry-over in cross-over trials in bioequivalence: Theoretical concerns and empirical evidence. Pharm. Stat. 2004, 3, 133-142. [CrossRef]

62. Food and Drug Administration. Bioequivalence Testing; Guidance for Industry; Food and Drug Administration: Rockville, MD, USA, 2006.

63. Food and Drug Administration. Bioequivalence Studies with Pharmacokinetic Endpoints for Drugs Submitted Under an ANDA; Guidance for Industry; Food and Drug Administration: Rockville, MD, USA, 2013.

64. Jones, G. Pharmacokinetics of vitamin D toxicity. Am. J. Clin. Nutr. 2008, 88, 582S-586S. [CrossRef] 
65. Jones, G. Interpreting vitamin D assay results: Proceed with caution. Clin. J. Am. Soc. Nephrol. 2015, 10, 331-334. [CrossRef]

66. Farrell, C.-J.L.; Martin, S.; McWhinney, B.; Straub, I.; Williams, P.; Herrmann, M. State-of-the-Art Vitamin D Assays: A Comparison of Automated Immunoassays with Liquid Chromatography-Tandem Mass Spectrometry Methods. Clin. Chem. 2012, 58, 531-542. [CrossRef] [PubMed]

67. Black, L.J.; Anderson, D.; Clarke, M.W.; Ponsonby, A.-L.; Lucas, R.M.; Group, A.I. Analytical Bias in the Measurement of Serum 25-Hydroxyvitamin D Concentrations Impairs Assessment of Vitamin D Status in Clinical and Research Settings. PLoS ONE 2015, 10, e0135478. [CrossRef] [PubMed]

68. Silva, M.C.; Furlanetto, T.W. Intestinal absorption of vitamin D: A systematic review. Nutr. Rev. 2018, 76, 60-76. [CrossRef] [PubMed]

69. Rees, J.R.; Mott, L.A.; Barry, E.L.; Baron, J.A.; Bostick, R.M.; Figueiredo, J.C.; Bresalier, R.S.; Robertson, D.J.; Peacock, J.L. Lifestyle and Other Factors Explain One-Half of the Variability in the Serum 25-Hydroxyvitamin D Response to Cholecalciferol Supplementation in Healthy Adults. J. Nutr. 2016, 146, 2312-2324. [CrossRef] [PubMed]

70. Bouillon, R. Genetic and environmental determinants of vitamin D status. Lancet 2010, 376, 148-149. [CrossRef]

71. Paschou, S.A.; Anagnostis, P.G.; Muscogiuri, G.; Goulis, D.G.; Vryonidou, A. Letter to the Editor: Genetics and Vitamin D Supplementation in Pregnancy. J. Clin. Endocrinol. Metab. 2017, 102, 3563-3564. [CrossRef]

72. Moon, R.J.; Harvey, N.C.; Cooper, C.; D'Angelo, S.; Curtis, E.M.; Crozier, S.R.; Barton, S.J.; Robinson, S.M.; Godfrey, K.M.; Graham, N.J.; et al. Response to Antenatal Cholecalciferol Supplementation Is Associated With Common Vitamin D-Related Genetic Variants. J. Clin. Endocrinol. Metab. 2017, 102, 2941-2949. [CrossRef]

73. Grant, W.B.; Boucher, B.J. Why Secondary Analyses in Vitamin D Clinical Trials Are Important and How to Improve Vitamin D Clinical Trial Outcome Analyses-A Comment on “Extra-Skeletal Effects of Vitamin D, Nutrients 2019, 11, 1460". Nutrients 2019, 11, 2182. [CrossRef]

74. Pritchard, L.; Lewis, S.; Hickson, M. Comparative effectiveness of vitamin D supplementation via buccal spray versus oral supplements on serum 25-hydroxyvitamin D concentrations in humans: A systematic review protocol. JBI database Syst. Rev. Implement. reports 2019, 17, 487-499. [CrossRef]

75. Guyatt, G.H.; Oxman, A.D.; Vist, G.E.; Kunz, R.; Falck-Ytter, Y.; Alonso-Coello, P.; Schünemann, H.J.; GRADE Working Group. GRADE: An emerging consensus on rating quality of evidence and strength of recommendations. BMJ 2008, 336, 924-926. [CrossRef]

76. Saldanha, I.J.; Li, T.; Yang, C.; Owczarzak, J.; Williamson, P.R.; Dickersin, K. Clinical trials and systematic reviews addressing similar interventions for the same condition do not consider similar outcomes to be important: A case study in HIV/AIDS. J. Clin. Epidemiol. 2017, 84, 85-94. [CrossRef] [PubMed]

77. Siontis, K.C.; Hernandez-Boussard, T.; Ioannidis, J.P.A. Overlapping meta-analyses on the same topic: Survey of published studies. BMJ 2013, 347, f4501. [CrossRef] [PubMed] 